\title{
KEBERHASILAN MENGEMBANGKAN SOSIAL AUD MELALUI TEKNIK MODELING
}

\author{
Nurfaizah $^{1}$, Romlah $^{2}$ \\ Universitas Islam Negeri Sunan Kalijaga Yogyakarta, Indonesia \\ Universitas Islam Negeri Raden Intan Lampung, Indonesia \\ faiznurfaizah21@gmail.com
}

\begin{abstract}
This study discusses to discuss the application of modeling techniques to develop social abilities of children aged 5-6 years. Social development for processes that require the ability to behave in accordance with social protection. Many social skills in students are still not well developed. Therefore, educators try to implement direct modeling techniques to see students' social development. The subjects in this study were 22 B2 class students at one of the schools in Bandar Lampung. The method used in this research is descriptive qualitative by describing the modeling techniques used to understand the development of social abilities. In this study using data collection techniques provided interviews, observation and documentation. Data analysis procedures using the theory of Milles and Hubberman, namely data reduction, data presentation and conclusion. The results of this study, students began to show good social development, such as being able to establish relationships properly, want to work together, want to share food and toys, and have a high sense of caring.
\end{abstract}

Keywords: Modeling Techniques; Social Ability; success

\begin{abstract}
Abstrak
Penelitian ini bertujuan untuk menganalisis mengenai pelaksanaan teknik modeling untuk mengembangkan kemampuan sosial anak usia 5-6 tahun. Perkembangan sosial ialah proses perolehan kemampuan berprilaku yang disesuaikan dengan tuntutan sosial.Kemampuan sosial pada peserta didik banyak yang masih belum berkembang dengan baik. Oleh karena itu, pendidik mencoba melaksanakan teknik modeling secara langsung untuk melihat perkembangan sosial peserta didik. Subyek dalam penelitian ini ialah 22 peserta didik kelas B2 disalah satu sekolah yang berada di Bandar Lampung. Metode yang digunakan dalam penelitian ini adalah deskriptif kualitatif dengan mendeskripsikan teknik modeling yang digunakan untuk mengetahui perkembangan kemampuan sosial. Dalam penelitian ini menggunakan teknik pengumpulan data diantaranya ialah wawancara, observasi dan dokumentasi. Prosedur analisis data menggunakan teori milles dan hubberman yakni reduksi data, penyajian data dan penarikan kesimpulan. Hasil penelitian ini, peserta didik mulai menunjukkan perkembangan sosial yang baik, seperti mampu menjalin hubungan dengan baik, mau bekerja sama, mau berbagi makanan dan mainan, dan memiliki rasa peduli yang tinggi.
\end{abstract}

Kata Kunci : Teknik Modeling; Kemampuan Sosial; Keberhasilan 


\section{PENDAHULUAN}

Pendidikan anak usia dini (Dewi, 2016) disebut juga sebagai pendidikan pra sekolah yang didalamnya terdapat pembelajaran ataupun pengalaman awal yang bisa memengaruhi masa yang akan datang. Disebut demikian karena anak usia dini adalah masa keemasan dan juga masa kritis dalam kehidupan anak. Oleh karenanya, pada masa inilah waktu yang tepat untuk meletakkan dasar bagi pengembangan berbagai potensi anak dan juga pendidikan karakter.

Pendidik, calon pendidik, dan pihak yang memerhatikan pendidikan anak khususnya anak usia dini, dibutuhkan pemahaman dan pengetahuan yang luas mengenai perkembangan dan kemajuan peserta didik (Anggraini, 2019). Sebab, pada masa anak usia dini anak mengalami masa keemasan yang merupakan masa dimana anak mulai sensitif untuk belajar dan merupakan awal anak untuk belajar sehingga mudah peka dengan berbagai rangsangan (Nurlaeni, 2017). Namun, Masa peka setiap individu bisa berbeda-beda seiring dengan laju tumbuh kembangnya masing-masing (Hermoyo, 2015). Maka perlu pemahaman untuk memahami hal tersebut sehingga pencapaian perkembangan bisa selaras antara peserta didik satu dan yang lainnya.

Pemberian stimulus dan fasilitas yang tepat pada masa anak usia dini akan sangat berpengaruh pada proses perkembangan peserta didik (Ananda, 2018). Pengalaman yang menyenangkan yang akan menjadi jalur dalam bereksplorasi adalah hakikat pembelajaran pada anak usia dini (Musi, 2018). Keberhasilan dalam menjalankan tugas perkembangan pada masa sekarang akan berpengaruh dengan keberhasilan perkembangan dimasa mendatang (Fauziddin, 2016). Bisa dipahami bahwa, pendidikan anak usia dini memang sangat membutuhkan pengetahuan serta pengalaman dari seorang pendidik dalam memberikan pembelajaran kepadanya. Karena setiap individu dari anak usia dini berbeda-beda penanganannya, itulah menjadi alasan mendasar untuk pendidik agar memiliki pengetahuan yang luas supaya pendidik mampu memahami setiap individu sehingga pembelajaran dapat tersampaikan dan diterima dengan baik.

Pendidikan berfungsi sebagai fasilitator yang memiliki peran besar untuk mengerahkan peserta didik pada pemahaman yang bermakna, sebagai fasilitator pendidik dapat memberikan kemudahan belajar pada peserta didik demi terwujudnya tujuan pembelajaran (Anwar, 2017). Guru atau pendidik disebut juga sebagai jembatan untuk membantu peserta didik memasuki pendidikan selanjutnya dilihat dari sisi akademik, nilai dan 
norma agama serta mengajarkan pembiasaan tingkah laku yang baik (Munawaroh, 2017). Hal ini bisa dilakukan dengan menggunakan metode dan media yang tepat untuk membantu memudahkan proses pembelajaran sehingga bisa mewujudkan tujuan pembelajaran yang diharapkan. Pendidik sebagai fasilitator diantaranya: pendidik harus biasa menciptakan suasana awal, situasi kelompok dan juga pengalaman kelas; pendidik juga harus bisa mempercayakan peserta didik untuk melaksanakan tujuan-tujuan yang bermakna bagi dirinya; pendidik bisa mengambil inisiatif untuk ikut serta dalam kelompok dan bisa menuangkan perasaaan dan ide pikirannya sebagai peserta didik bukan sebagai pendidik; dan sebagai pendidik harus bisa mengenali dan menerima keterbatasannya. Bisa dimengerti bahwa tugas pendidik bukan hanya sekedar mengajar, selesai dan pulang. Namun, tugas pendidik juga harus mampu untuk menggali ide untuk memudahkan peserta didik memahami pembelajaran yang diajarkan, sehingga mudah bagi peserta didik untuk mencapai tujuan pembelajaran yang diharapkan.

Pendidikan anak usia dini merupakan pendidikan yang diselenggarakan untuk anak usia 0 sampai enam tahun (Megawardani, 2018). Setiap anak memiliki tingkatan pendidikan yang berbeda-beda mulai dari pendidikan keluarga, lanjut ke taman penitipan anak, kemudian kelompok bermain dan terakhir taman kanak-kanak. Pendidikan anak usia dini diselenggarakan untuk membantu memfasilitasi dan merangsang semua aspek tumbuh kembang anak supaya dapat tumbuh dan berkembang secara optimal. Hakikat anak usia dini ialah individu yang unik, mempunyai pola tumbuh kembang dalam berbagai aspek. Terdapat enam aspek yaitu; agama dan moral, fisik motorik, kognitif, bahasa, sosial emosional dan juga seni (Pebriana, 2017). Dalam kaitannya dengan penelitian kali ini, peneliti memfokuskan kepada perkembangan sosial anak usia dini.

Perkembangan sosial (Nugraha, 2014) ialah proses memperoleh kemampuan berprilaku yang disesuaikan dengan tuntutan sosial. Proses tersebut terbagi menjadi tiga, diantaranya: belajar berperilaku dengan cara yang bisa diterima oleh masyarakat, belajar berperilaku untuk berperan sosial dimasyarakat, dan mengembangkan sikap sosial dan aktivitas sosial yang ada dimasyarakat. Dapat dipahami bahwa perkembangan sosial dapat berkembang baik dengan mengikuti beberapa proses yang sesuai dengan tuntunan sosial masyarakat disekitarnya, sehingga akan sangat mudah diterima di masyarakat jika sudah sesuai dengan tuntunan sosial yang berlaku. Jika dikaitkan dengan kemampuan sosial anak usia dini, maka perlu adanya stimulus dari luar dirinya untuk bisa diterima di lingkungannya. 
Perlu adanya pengertian tentang pentingnya memiliki sosial yang baik serta dampak yang akan diterima jika mengabaikan hal tersebut. bisa dengan memberikan contoh perilaku sosial, sebab dan akibat dari perilaku tersebut. Sebab, jika sejak dini tidak diperhatikan tentang kemampuan sosialnya, amat sangat mengkhawatirkan jika anak usia dini berperilaku sesuai yang ia kehendaki tanpa memikirkan aturan sosial yang berlaku, maka akan membawa dampak pada dirinya untuk sulit diterima dilingkungan belajar, lingkungan bermain dan leboih luas yakni lingkungan masyarakat.

Kemampuan sosial (Goleman, 2017) dapat membuat seseorang untuk membangun hubungan dengan orang lain, dapat menggerakkan dan juga mengilhami orang lain, mampu mempererat hubungan dengan orang lain, mampu meyakinkan dan memengaruhi orang lain, baik dalam hal perkataan maupun perilaku, serta mampu menciptakan kenyamanan bagi dirinya dan juga orang lain. Bisa dipahami bahwa kemampuan sosial seseorang bisa dilihat dari mampu menjalin hubungan yang baik dan menciptakan kenyamanan bagi dirinya dan oranglain tanpa adanya paksaan dari pihak manapun. Jika seseorang memiliki sosial yang baik, maka akan memudahkan dirinya untuk bisa dipercaya dengan orang lain, mendapat pandangan sosial yang baik, dan semua tingkah laku yang ia lakukan bisa memengaruhi orang lain untuk menjadi pribadi yang lebih baik tentunya. Tidak berbeda dengan anak usia dini, mereka juga mempunyai kehidupan sosial yang berbeda dari orang dewasa. Jika orang dewasa lingkup sosialnya tentang pekerjaan, pendidikan dan lain sebagainya. Maka, anak usia dini mempunyai lingkup sosial untuk belajar sambil bermain. Dalam dua hal itu, maka diperlukan adanya kemampuan sosial yang baik, yang bisa ditanamkan kedalam diri anak usia dini agar mereka tidak kesulitan untuk menjalin hubungan pertemanan dengan anak yang lain, dan meminimalisir pengucilan sosial dan sebagainya.

Kecerdasan sosial ialah kemampuan seseorang untuk dapat mengatur hubungan sosial dirinya dengan orang lain, menjaga emosi, mampu introspeksi diri, memiliki rasa empati, dan juga keterampilan sosial (Robbiyah, 2018). Perkembangan sosial ialah kemampuan berperilaku baik dengan teman, orang tua dan masyarakat supaya bisa menyesuaikan diri (Rahmadianti, 2020). Ketika seorang anak mampu untuk menjalin hubungan dengan temantemannya, berarti ia sudah mulai cakap perkembangan sosialnya. Berkemampuan sosial yang baik pada diri seorang anak juga diperlukan, supaya tidak terjadi permasalahan- permasalahan yang tidak diinginkan. Seperti bullying di dalam maupun diluar sekolah misalnya, dan lain sebagainya. Manusia tidak bisa hidup sendiri, manusia butuh orang lain dalam menjalani 
kehidupan, tidak terkecuali juga anak usia dini. Mereka juga butuh teman untuk mengobrol, butuh teman untuk diajak bermain, butuh penghargaan atas dirinya dari orang lain, dan masih banyak lagi. Itulah pentingnya seseorang untuk memiliki kemampuan sosial yang baik.

Dari beberapa pengertian diatas dapat diambil kesimpulan bahwa kemampuan sosial adalah kecakapan seseorang untuk bergaul, menyesuaikan diri dengan lingkungan masyarakat sehingga memudahkan seseorang itu sendiri untuk mampu menjalin hubungan yang baik dengan orang lain dan menciptakan rasa nyaman dalam dirinya dan juga orang lain tanpa adanya tekanan dari pihak manapun. Ketika seorang anak usia dini tidak diajarkan berprilaku sosial yang baik, maka akan membawa dampak dalam dirinya sendiri untuk sulit diterima di lingkungannya. Namun, jika anak usia dini sudah mulai diajarkan tentang sosial yang baik, maka akan mudah bagi dirinya untuk bisa diterima dan menjalin hubungan dengan orang lain dalam lingkungannya. Pengenalan dan pengajaran sosial tidak hanya berdampak dimasa sekarang, namun juga akan berpengaruh dimasa yang akan datang. Maka, sangat dibutuhkan stimulus untuk membantu perkembangan sosial anak usia dini yang dilakukan oleh orang tua dirumah, guru disekolah, dan juga orang dewasa dilingkungan masyarakat agar bisa memberikan nasehat, bimbingan, dan juga menjadi teladan ataupun contoh yang baik untuk anak usia dini supaya memiliki perilaku sosial yang baik sehingga akan merasa nyaman dalam menjalani kehidupan bersosial.

Dalam proses perkembangan sosial anak usia dini perlu adanya contoh teladan atau modeling dalam proses belajar sambil bermain di TK. Sebagai seorang pendidik, sudah hal yang tidak asing untuk selalu melihat perkembangan dari peserta didik salah satunya yakni kemampuan sosial peserta didik. Dalam mengembangkan kemampuan sosial peserta didik, maka pendidik bisa dengan memberikan bimbingan berupa nasihat atau motivasi dan peserta didik dapat menuruti nasihat yang diberikan oleh pendidik. Namun, peserta didik adalah peniru ulung. Oleh karenanya peserta didik dapat melihat dan meniru apapun yang dilakukan pendidik baik hubungan pendidik dengan peserta didik atau dengan sesama pendidik.

Modeling (Komalasari, 2011) berakar dari teori Albert Bandura dengan teori belajar sosial. Modeling berarti belajar melalui observasi dengan cara menambah atau mengurangi perilaku yang diamati, menyimpulkan dari berbagai hal yang diamati sekaligus melibatkan otak untuk berpikir (proses kognitif). Peserta didik mudah meniru tingkah laku yang ia lihat dimanapun dan kapanpun. Oleh karenanya, sebagai orang tua dan juga guru sebagai 
pendidik disekolah harus bisa mencontohkan dan mengajarkan perilaku yang baik sehingga anak akan mengimitasi perilaku tersebut. Semakin sering perilaku baik itu diajarkan, semakin sering perilaku baik dilaksanakan maka akan semakin melekat dan tertanam kuat dalam diri peserta didik untuk berperilaku sesuai yang diharapkan, baik itu dari sisi peserta didik mapun lingkungan sekitar.

Modelling berasal dari bahasa inggris yang berarti mencontoh, meniru, memperagakan, atau meneladani (Herdian, 2019). Semua kehidupan sosial, sebenarnya berpacu pada faktor imitasi, berarti perilaku seseorang bisa didapat dari hasil pengamatan (Suharsiwi, 2015). Artinya, semua perilaku seseorang dalam kehidupan ini didapat dari meniru perilaku orang lain dengan cara mengamatinya lalu dilakukannya dalam kehidupan sosial. Pada anak usia dini, mereka akan fokus meniru perilaku yang ia lihat. Baik itu dengan teman sebayanya, orang tuanya, gurunya, dan lain sebagainya.

Teknik modeling (Repita, 2016) adalah proses seorang individu mengamati seorang model dan kemudian diperkuat untuk mencontoh tingkah laku sang model. Peserta didik dalam hal ini akan mengamati orang lain yakni guru yang akan menjadi model, yang kemudian peserta didik akan diberikan penguatan untuk meniru perilaku tersebut dengan memberikan pencontohan tingkah laku yang dikehendaki.

Dari beberapa pemaparan diatas dapat disimpulkan bahwa teknik modeling berarti proses mengamati tingkah laku yang melibatkan proses kognitif untuk mempertimbangkan apakah perilaku tersebut baik untuk dicontoh atau tidak. Dalam proses pembentukan dan pemilihan perilaku yang diamati, maka peserta didik pada anak usia dini perlu bimbingan serta penguatan-penguatan dalam membentuk perilaku dalam dirinya, baik menambahi atau mengurangi perilaku yang diamati sehingga dapat membentuk perilaku baru yang sesuai dengan tuntutan sosial masyarakat.

Pembentukan perilaku melalui teknik modeling terbagi menjadi 3, yaitu: a) modeling nyata, yaitu model yang dapat dilihat dan diamati oleh peserta didik secara nyata dalam kehidupan sehari-hari sehingga peserta didik dapat langsung melihat dan berinteraski dengan model tersebut. b) model simbolik, yaitu perilaku model yang ingin dibentuk pada diri peserta didik disajikan dalam bentuk video, film, atau bentuk symbol lainnya. c) modeling ganda, merupakan gabungan dari modeling nyata dan modeling simbolik. 
Jenis model yang dipilih dalam penelitian ini adalah modeling nyata yang dilakukan oleh guru /pendidik karena dirasa peserta didik akan lebih mudah mengikuti dan meniru perilaku gurunya yang setiap saat bersama mereka sehingga peserta didik akan lebih mudah terbiasa untuk meniru perilaku yang dicontohkan atau dilakukan oleh guru/pendidik.

Modeling melibatkan empat proses (Sutama, 2014), yaitu: a) Attentional, ini adalah fase dimana peserta didik menaruh perhatian dan mencoba mengamati perilaku model. Dalam tahap ini, tugas model/guru harus bisa mengambil perhatian peserta didik, bisa dengan media, dengan lagu, dengan tepuk, dan semua hal-hal yang akan membuat peserta didik merasa tertarik dengan pembawaan model/ guru. Sehingga, ketika fokus peserta didik sudah kepada model/guru, maka akan memudahkan model atau guru untuk masuk kedalam tahap berikutnya. b) Retention, yaitu fase peserta didik memasukkan perilaku model kedalam memori otaknya dan akan menirunya. Oleh karenanya dalam tahap ini pendidik sebagai model harus bisa memperhatikan apapun yang ia lakukan dan ucapkan. penerapan intonasi suara dan mimik muka juga diperlukan dalam tahap ini, supaya peserta didik tidak mudah merasa bosan. c) Production, yaitu peserta didik mulai melakukan tingkah laku baru yang ia amati, dalam tahap ini peran pendidik perlu untuk mengontrol apakah perilaku yang peserta didik amati dan lakukan sudah sesuai dengan perilaku yang dicontohkan atau belum. Jika hasil belum mencapai hasil yang diharapkan maka perlu umpan balik dari pendidik untuk memperbaiki perilaku peserta didik. Namun, jika perilaku yang dilakukan peserta didik sudah sesuai dengan perilaku sosial yang baik, maka model atau guru bisa masuk kedalam tahap selanjutnya. d) Motivational, tahap ini adalah ketika peserta didik sudah mampu mengimitasi dari perilaku yang ia amati. Maka dalam tahap ini pula peserta didik perlu penguatan atas perilaku yang ia tiru. Bisa berupa pujian atau hal-hal yang menyenangkan hati peserta didik. Hal ini tentu sangat diperlukan supaya peserta didik konsisten dan terbiasa dengan perilaku sosial yang baik, dan bisa mempengaruhi peserta didik yang lain untuk mau melakukan perilaku sosial yang baik pula.

Untuk mengetahui bagaimana tingkat perkembangan sosial peserta didik dengan menggunakan teknik modeling, maka dalam penelitian ini, peneliti akan menyajikan hasil penelitian mengenai teknik modeling untuk mengembangkan kemampuan sosial anak usia dini di TK ‘Aisyiyah Bustanul Athfal 1 Bandar Lampung. 


\section{METODE PENELITIAN}

Metode penelitian yang digunakan oleh peneliti adalah penelitian kualitatif. (Moleong, 2017) menyebutkan bahwa, penelitian kualitatif ialah penelitian yang menggunakan latar belakang ilmiah, dengan menjabarkan fenomena yang ditemui dilapangan dan melibatkan berbagai metode yang ada dalam penelitian kualitatif. Data yang akan peneliti deskripsikan adalah teknik modelling yang digunakan untuk mengembangkan kemampuan sosial anak yang dilakukan oleh pendidik di TK 'Aisyiyah Bustanul Athfal 1 Bandar Lampung. Subyek dalam penelitian ini adalah 22 peserta didik kelas B2 TK 'Aisyiyah Bustanul Athfal 1 Bandar Lampung. Pengumpulan data dalam penelitian ini menggunakan wawancara, observasi dan dokumentasi. Sedangkan dalam menganalisis data dengan menggunakan teori milles dan hubberman yakni reduksi data, penyajian data dan penarikan kesimpulan.

\section{HASIL PENELITIAN DAN PEMBAHASAN}

Berdasarkan pengamatan yang dilakukan peneliti dalam proses pelaksanaan teknik modeling untuk mengembangkan kemampuan sosial peserta didik, menunjukkan beberapa perubahan perilaku sosial yang baik dari peserta didik kelas B2. Diantaranya yaitu; a) peserta didik yang awalnya hanya mau berteman dengan dua atau tiga orang, sekarang sudah mulai menunjukkan perilaku mau menerima kehadiran teman baru dalam permainannya, b) peserta didik yang tidak mau bekerjasama dalam tugas kelompok sudah mulai membiasakan diri, c) peserta didik yang amat sangat pelit sudah mau berbagi sedikit demi sedikit makanan yang dibawanya atau juga mau bergantian dalam menggunakan alat permainan, d) peserta didik yang acuh dengan keadaan temannya sudah mulai menunjukkan rasa peduli, seperti yang awalnya tidak mempedulikan temannya yang menangis mulai bisa menenagkan temannya, saat temannya kehilangan suatu barang seperti penghapus maka teman yang satunya mulai mau meminjamkan penghapusnya, dan masih banyak lagi.

Anak usia dini adalah peniru ulung, jika kita ingin membentuk perilaku yang baik, maka tampilkan yang baik-baik di depan mereka. Modeling adalah teori belajar sosial yang digagas oleh Bandura sebagai belajar sosial. Modeling mengenalkan cara pembentukan perilaku melalui proses pengamatan terhadap orang lain sehingga membentuk perubahan perilaku yang terjadi melalui peniruan. Proses pengamatan perilaku secara langsung dengan penokohan nyata yang diperankan oleh guru atau pendidik menunjukkan perkembangan yang baik pada peserta didik. 
Attentional, adalah fase dimana peserta didik menaruh perhatian dan mencoba mengamati perilaku model. Yang dilakukan guru untuk membuat focus peserta didik menuju kepada apa yang akan guru tampilkan di depan mereka adalah merubah posisi tempat duduk. Untuk menangani peserta didik yang hyperaktif di posisikan lebih dekat dengan guru dengan maksud agar peserta didik mampu menyimak dan focus perhatiannya dengan apa yang akan guru ucapkan atau lakukan. Hasil dari pengamatan peneliti, setelah peserta didik fokus, maka guru akan mengajak peserta didik untuk menggunakan imajinasinya mengikuti alur cerita yang disampaikan dan diperagakan oleh guru. Dalam tahap pertama ini memang tidak mudah untuk menarik perhatian dan fokus dari peserta didik, oleh karenanya, guru mencoba untuk mengalihkan perhatian peserta didik dengan hal-hal yang menyenangkan dan di sukai oleh seluruh peserta didik, seperti bernyanyi, bertepuk, melompat, dan berputar. Setelah itu, baru guru secara perlahan mulai memperagakan dirinya sebagai seorang tokoh yang dikehendaki, guru juga mulai mengatur intonasi suara beserta mimik muka, sehingga penokohan yang dilakukan guru tidak berjalan monoton. Hal ini tentunya menarik perhatian peserta didik untuk mulai tertarik dengan penokohan guru.

Retention, yaitu fase peserta didik memasukkan perilaku model kedalam memori otaknya dan akan menirunya. Oleh karenanya dalam tahap ini pendidik sebagai model harus bisa memperhatikan apapun yang ia lakukan dan ucapkan. Bahasa yang digunakan guru, juga merupakan bahasa yang mudah dimengerti oleh peserta didik, bukan menggunakan bahasabahasa istilah, bahasa ilmiah dan lain sebagainya. Tujuannya, supaya pembelajaran yang disampaikan mampu diterima dan bisa tersimpan kedalam memori otak peserta didik dengan baik, sehingga akan muncul perilaku yang sesuai dengan tujuan pembelajaran yang di inginkan. Untuk menstimulus daya ingat peserta didik, biasanya guru akan memberikan pertanyaan kepada peserta didik berupa sebab akibat dari perilaku yang dicontohkan atau diperankan oleh guru. Dalam praktek pengajaran, guru menampilkan dan memerankan tokoh imajiner dalam ceritanya dengan baik. Peneliti juga melihat bahwa perilaku baik itu tidak hanya ada dalam tokoh imajiner cerita, namun juga ada dalam pribadi guru. Terlihat ketika jam istirahat, atau di jam lain sebelum proses pembelajaran, para guru sering membagi makanan yang mereka miliki, saling berjabat tangan ketika bertemu, saling membantu dalam menangani masalah di kelas, dan memiliki rasa peduli terhadap sesamanya. Hal ini supaya 
peserta didik merekam kedalam otaknya perilaku yang baik yang bisa dipraktekkan secara nyata.

Production, yaitu peserta didik mulai melakukan tingkah laku baru yang ia amati, dalam tahap ini peran pendidik perlu untuk mengontrol apakah perilaku yang peserta didik amati dan lakukan sudah sesuai dengan perilaku yang dicontohkan oleh guru atau belum. Ketika perubahan perilaku sosial peserta didik mulai terlihat, maka untuk melatih dan mengembangkan perilaku baik tersebut, peneliti melihat guru sengaja menaruh wadah makanan berupa piring kosong yang diletakkan ditengah lingkaran pada saat jam istirahat/makan yang nantinya akan dibagikan kembali pada peserta didik yang lupa membawa bekal,dsb. Hal ini dimaksudkan untuk melatih kepekaan peserta didik, apakah mereka rela membagi makanannya untuk orang lain atau tidak. Hasil dari penelitian, ternyata peserta didik banyak yang peka dengan hal itu, bahkan peserta didik bercerita jika sudah mempersiapkan khusus makanan untuk dirinya dan makanan untuk dibagikan dengan yang lain. Tidak jarang peserta didik laporan dengan guru jika ia tidak membagi makanan dipiring karena sudah membagi makanannya langsung ke teman sebelahnya. Hal ini tentu adanya perubahan sosial yang baik pada diri peserta didik, karena dalam dirinya ia sudah ada kemauan untuk membagi sesuatu yang ia miliki.

Pada waktu yang berbeda, terlihat peserta didik yang mulai membaur dengan teman yang lain. Padahal sebelumnya, mayoritas peserta didik hanya mau berteman dengan dua sampai empat orang saja. Namun, perubahan sosial mulai menjadi baik, mereka mulai tidak pilih-pilih teman. Bahkan saat jam istirahat, biasanya bergerombol 4 sampai 5 kelompok dalam kelas. Namun, ternyata kemampuan sosial peserta didik mulai berkembang dengan baik, peneliti melihat mereka bermain dalam satu kelompok besar, dan dalam kelompok besar tersebut ketika ada yang menangis karena rebutan mainan, maka teman yang lain akan menenangkan teman yang nangis tersebut. sebagian teman yang lain akan membujuk peserta didik yang menyebabkan temannya nangis untuk meminta maaf dan berjabat tangan. Hal ini menunjukkan perilaku yang baik sehingga terciptalah hubungan sosial yang baik antar peserta didik dan juga guru.

Motivational, tahap ini adalah ketika peserta didik sudah mampu mengimitasi dari perilaku yang ia amati. Maka dalam tahap ini pula peserta didik perlu penguatan atas perilaku yang ia tiru. Bisa berupa pujian atau hal-hal yang menyenangkan hati peserta didik. Hasil 
pengamatan peneliti, guru biasanya memberikan penghargaan kepada peserta didik yang berperilaku baik dengan mengelus kepalanya, bahkan peserta didik membalasnya dengan memberikan pelukan kepada guru. Terkadang juga memberikan penghargaan dengan penyebutan anak jempol yang berarti anak hebat. Meskipun reward yang diberikan guru terhadap peserta didik yang mulai berperilaku sosial baik hanya sebatas hal-hal sederhana bahkan bisa dikatakan reward tanpa biaya, namun hal itu amat sangat membuat peserta didik merasa senang, bahkan tidak jarang ditemui peserta didik yang lain ikut termotivasi untuk berperilaku sosial yang baik terhadap sesama peserta didik dan juga kepada guru. Meskipun, mungkin niatan awal peserta didik berperilaku sosial baik untuk tujuan tertentu, yakni berupa pujian yang diberikan guru dan lain sebagainya. Namun, seiring berjalannya waktu, perilaku sosial peserta didik yang ditanam sejak dini akan menjadi kebutuhan dan bagian dalam dirinya dimasa-masa selanjutnya tanpa meminta imbalan dari guru maupun orang lain.

\section{SIMPULAN DAN SARAN}

Berdasarkan pengamatan yang dilakukan peneliti di kelas B2 menunjukkan perubahan perilaku peserta didik yang baik setelah dilakukan pembiasaan yang baik yang ditampilkan dari perilaku model. Peneliti menyimpulkan bahwa penerapan teknik modeling dapat mengembangkan kemampuan sosial anak usia 5-6 tahun di TK 'Aisyiyah Bustanul Athfal 1 Bandar Lampung.

Untuk meningkatkan mutu pendidikan selanjutnya, maka peneliti mengemukakan beberapa saran yaitu : kepada guru kelas, agar jangan lengah untuk memberikan reward kepada setiap peserta didik meskipun hanya sekedar acungan jempol, hal ini dimaksudkan sebagai pupuk agar perilaku sosial yang baik itu bisa tertanam kuat dalam diri peserta didik. Kepada para orang tua, agar ikut andil dalam proses pembentukan perilaku sosial yang baik dalam diri peserta didik, bisa dengan modeling dan juga reward seperti yang guru lakukan disekolah atau dengan cara lain yang dirasa mampu membantu perkembangan kemampuan sosial anaknya.

\section{DAFTAR PUSTAKA}

Agus Sutama, Gede, dkk. (2014). Penerapan Teori Behavioral dengan Teknik Modeling Untuk Meningkatkan Kemandirian Belajar Siswa Kelas AK C SMK Negeri Singaraja. e-journal Undiksa Jurusan Bimbingan Konseling. Vol.2 No.1. http://dx.doi.org/10.23887/jibk.v2i1.3960 
Ananda, Rizki dan Fadhilaturrahmi Fadhillaturahmi. (2018). Peningkatan Kemampuan Sosial Emosional Melalui Permainan Kolaboratif pada Anak KB. Jurnal Obsesi: Jurnal Pendidikan Anak Usia Dini 2(1), 20-26. https://doi.org/10.31004/obsesi.v2i1.3

Anggraini, W., \& Kuswanto, C. W. (2019). Teknik Ceklist Sebagai Asesmen Perkembangan Sosial Emosional di RA. Al-Athfaal: Jurnal Ilmiah Pendidikan Anak Usia Dini, 2(2), 61-70. https://doi.org/10.24042/ajipaud.v212.5248

Anwar, Chairul. (2017). Teori-Teori Pendidikan Klasik Hingga Kontemporer. Banguntapan Yogyakarta: IRCiSoD.

Eka Repita, Luh, dkk. (2016). Implementasi Teknik Modeling Untuk Meminimalisasi Perilaku Bermasalah Opposotional Defiant Pada Anak Kelompok B. e-Journal Pendidikan Anak Usia Dini Universitas Pendidikan Ganesha Jurusan Pendidikan Guru Pendidikan Anak Usia Dini. Vol.4, No.2. http://dx.doi.org/10.23887/paud.v4i2.7635

Eva Megawardani, Ni Kadek. Ni Ketut Suarni dan Luh Ayu Tirtayani. (2018). Meningkatkan Keterampilan Sosial Melalui Penerapan Teknik Modeling pada Anak Kelompok B TK Saiwa Dharma. e-Journal Pendidikan Anak Usia Dini Universitas Pendidikan Ganesa. Vol. 4 No. 3. http://dx.doi.org/10.23887/paud.v4i3.8814

Fauziddin,Moh. (2016). Peningkatan Kemampuan Kerja Sama melalui Kegiatan Kerja Kelompok Pada Anak Kelompok A Kartika Solo Kabupaten Kampar. Jurnal PGPAUD STKIP PTT. Vol.2 No.1. 29-45 http://doi.org/10.31004/obsesi.v2i1.47

Goleman, Daniel. (2017). Kecerdasan Emosional. Jakarta: PT Gramedia Pustaka Utama.

Herdian, Ade dan Frischa Meivilona Yendi. (2019). Teknik Modelling: Sebuah Alternatif dalam Peningkatan Self Efficacy Akademik. SCHOULID: Indonesia Journal of School Counseling. 4(3), 89-94. https://doi.org/10.23916/08412011

Hermoyo, Panji. (2015). Membentuk Komunikasi yang Efektif pada Masa Perkembangan Anak Usia Dini. Pedagogi: Jurnal Anak Usia Dini dan Pendidikan Anak Usia Dini. Vol.1 No.1 http://dx.doi.org/10.30651/pedagogi.v1i1.21

Komalasari, Gantina, dkk. (2011). Teori dan Teknik Konseling. Jakarta: Indeks.

Komang Erlina Dewi, I Desak., dkk. (2016). Penerapan Teknik Modeling untuk Meningkatkan Disiplin Pada Anak Usia 5-6 Tahun. e-Journal Pendidikan Anak Usia Dini Universitas Pendidikan Ganesha Jurusan Pendidikan Guru Pendidikan Anak Usia Dini, Vol.4, No.3. http://dx.doi.org/10.23887/paud.v4i3.8835

Moleong, Lexy J. (2017). Metode Penelitian Kualitatif. Bandung: PT Remaja Rosdakarya.

Munawaroh, Hidayatu. (2017). Pengembangan Model Pembelajaran dengan Permainan Tradisional Engklek Sebagai Sarana Stimulasi Perkembangan Anak Usia Dini. Jurnal 
Obsesi: Jurnal Pendidikan Anak Usia Dini. Vol. 1 No.2. 86-96 https://doi.org/10.31004/obsesi.v1i2.19

Musi, Muhammad Akil.,dkk. (2018). Kontribusi Bermain Peran untuk Mengembangkan Sosial Emosional Anak Usia Dini. Golden Age: Jurnal Pendidikan Anak Usia Dini. Vol.1 No.2 https://doi.org/10.29313/ga.v1i2.3315

Nugraha, Ali dan Yeni Rachmawati.(2014). Metode Pengembangan Sosial Emosional. Jakarta: Pusat Penerbitan Universitas Terbuka.

Nurlaeni dan Yenti Juniarti. (2017). Peran Orang Tua dalam Mengembangkan Kemampuan Bahasa Pada Anak Usia 4-6 Tahun. Jurnal Pelita PAUD. Vol.2 No.1https://doi.org/10.33222/pelitapaud.v2i1.196

Pebriana, Putri Hana. (2017). Analisis Penggunaan Gadget terhadap Kemampuan Interaksi Sosial pada Anak Usia Dini. Jurnal Obsesi. Vol.1 No.1, 1-11 https://doi.org./10.31004/obsesi.v1i1.26

Rahmadianti, Novia. (2020). Pemahaman Orang Tua Mengenai Urgensi Bermain dalam Meningkatkan Perkembangan Sosial Anak Usia Dini. Jurnal Pendidikan: Early Childhood. Vol.4 No.1. 57-64 https://doi.org/10.35568/earlychildhood.v4i1.717

Robbiyah, dkk. (2018). Pengaruh Pola Asuh Ibu terhadap Kecerdasan Sosial Anak Usia Dini di TK Kenanga Kabupaten Bandung Barat. Jurnal Obsesi: Jurnal Pendidikan Anak Usia Dini. Vol.2 No.2. 76-84. https://doi.org/10.31004/obsesi.v2i1.10

Suharsiwi. (2015). Pengembangan Model Pembelajaran Keterampilan Sosial Anak Autis di $\begin{array}{llllll}T K & B\end{array}$ Jurnal Ilmiah Visi PPTK PAUDNI. Vol.10 No.1. https://doi.org/10.21009/JIV.1001.1 